\title{
New distribution data for two species of the Neotropical genus Lathecla Robbins, 2004 (Lepidoptera, Lycaenidae, Eumaeini)
}

\author{
ZS. BÁLINT ${ }^{1}$, J. LORENC-BRUdECKA ${ }^{2} \&$ T. PYRCZ ${ }^{3}$ \\ ${ }^{1}$ Zsolt Bálint, Hungarian Natural History Museum, Department of Zoology, Budapest VIII \\ Baross utca 13,H-1088, Hungary.Email: balint@nhmus.hu \\ ${ }^{2}$ Jadwiga Lorenc-Brudecka, Zoological Museum of the Jagiellonian University, Gronostajowa 5, 30-387 \\ Kraków, Poland.Email: j.l@op.pl \\ ${ }^{3}$ Tomasz Wilhelm Pyrcz, Zoological Museum of the Jagiellonian University, Gronostajowa 5, 30-387 \\ Kraków, Poland.Email: tomasz.pyrcz@uj.edu.pl
}

\begin{abstract}
The species Lathecla carolyna Busby, 2015 described recently from Ecuador is reported to occur also in Venezuela and Colombia. An additional Peruvian occurrence of L. mimula (Draudt, 1920) is also documented.
\end{abstract}

Keywords. Colombia, Ecuador, wet forests, Peru, sampling, Venezuela.

\section{INTRODUCTION}

$\mathrm{T}$ he purpose of this present note is to contribute with new data to the knowledge of Lycaenidae faunistics in the light of recent publications, in this case for the genus Lathecla established by Robbins (in Robbins \& Duarte 2004). The genus was subsequently monographed (Robbins \& Busby 2015) and seven species have been diagnosed on the basis of 121 individuals assembled from the collections of eleven institutes.

In this paper we report on three specimens deposited in the collections of two institutes not inspected by the mentioned authors: Zoological Museum of the Jagiellonian University, Krakow (MZUJ) and the Department of Zoology, Hungarian Natural History Museum, Budapest (HN $\mathrm{HM})$. Although the sample is small, it contributes importantly to the knowledge on the distribution of a recently described species and on another's with historically confused nomenclature, therefore both poorly known, as well as their recently established genus.

The new records indicate that how undersampled is the Neotropical eumaeine fauna in the
Neotropics and any reliable distributional data is worth to publish for a better understanding of the diversity of the tribe.

\section{Lathecla carolyna Busby, 2015}

(Figure 1)

Lathecla carolyna Busby, new species - Robbins \& Busby 2015: 70, type locality: "Ecuador, Pichincha, Province Pandapi, 1800 m", (holotype, male, National Museum of Natural History, Washington, USA), fig. 6 (male and female wing surfaces), fig. 19 (male genitalia), fig. 24 (female genitalia).

Material examined. (2) VENEZUELA: "Edo. Táchira, P. N. Tamá, Fundo Piedra Blanca, 2450 m, 15-20.IX.1996, leg. F. Rey" (MZUJ: male; dissected); COLOMBIA: "Valle, Rio Aguacatal, S. Antonio, 2200 m, 3.2.2004." (HNHM: male, dissected, gen. prep. Bálint no. 1551).

Remarks. The species was described on the basis of the male holotype, and five male and three female paratypes, all from Ecuador, provinces Pichincha (holotype, plus three males, three females) and Morona-Santiago (two males). Although the Venezuelan specimen is slightly 
worn, the distinguishing characters are well visible: it has no black androconial patch in the anterior portion of dorsal hindwing surface, but a dark patch can be observed on the medial area of the ventral forewing inner margin, and blue scaling extends into the anterior portion of the dorsal forewing surface ( $c f$. Robbins \& Busby 2015, fig. 6).

As the Colombian specimen is heavily worn, a genital dissection was necessary to have more evidences for a positive identification. The male genitalia structures show all the diagnostic characters of $L$. carolyna illustrated in the figures accompanying the description, in particular a long and narrow shaped valva with pointed terminus in lateral aspect without terminal pincer-like extension, and an aedeagus deeply open dorsally ( $c f$. Robbins and Busby 2015, fig. 19).

\section{Lathecla mimula (Draudt, 1920)}

(Figure 2)

Thecla mimula sp. nov. - Draudt 1920: 793, type locality: "Pachitea (Peru)" (syntype(s), female, Forschungsinstitut und Naturmuseum Senckenberg, Frankfurt am Main, Germany), pl. 157g, fig. "mimula U".

Thecla latagus Godman \& Salvin, 1887 - d'Abrera 1995: 1258, 1259 fig. "T. latagus" [misidentification].

Lathecla mimula (Draudt, 1920) [new combination] Robbins 2004: 126, in synonymy of Lathecla latagus (Godman \& Salvin, 1887).

Lathecla mimula (Draudt, 1920), revised status Robbins \& Busby, 2015: 66, fig. 3 (male and female wing surfaces), fig. 15 (male genitalia), fig. 21 (female genitalia).

Material examined. (1) PERU: "San Martin, Juanjui, 18.X.2003." (coll. Pierre Boyer, to be deposited in MZUJ).

Remarks. The identity of the species and its generic placement has been clarified by Robbins \& Busby (2015), on the basis of 22 male and 14 female specimens. They described and documented both sexes for the first time. The male is distinctive having black coloured androconia on the dorsal wing surface, a character shared only with a single congener, L. latagus; but they can be easily differentiated on the basis of wing shape, coloration and pattern as L. mimula has less rounded outer margin, brighter blue dorsal structural colour with narrower black forewing border (cf. figures in d'Abrera 1995).

\section{DISCUSSION}

\section{Lathecla carolyna in Venezuela}

The report of $L$. carolyna in Venezuela is an important extension of the species' distribution range. In Venezuela, the species was found in a similar biotope as in Ecuador, in moist montane forest at $1800 \mathrm{~m}$ asl. The exact collecting place, the Fundo de Piedras Blancas above the locality of San Vicente de la Revancha in the Tama range on the Venezuela-Colombia border, the northern extremity of the Andean Eastern Cordillera (= GPS coordinates: N 7.502068; W 72.343147) is a place where several geographically extremely restricted species of butterflies are found including the unusual Catasticta revancha Rey \& Pyrcz, 1996, which is hitherto known only from this locality. The forest in Piedras Blancas is restricted to a river gulley and is surrounded by extensive potato and other crops plantations, and is therefore under a severe anthropogenic pressure. Interestingly, in the neighbouring Betania valley $L$. carolyna has not been collected so far, even though that this region has been much more intensely sampled for butterflies.

L. carolyna is the second species of the genus Lathecla recorded from Venezuela alongside $\mathrm{La}$ thecla fernandezi Robbins \& Busby, 2015. The two species can easily be distinguished on the basis of different wing shape and scaling as $L$. fernandezi has a more rounded inner forewing margin, and tan grey or white coloured androconia (see Robbins \& Busby 2015).

Based on the known distribution patterns indicated by Robbins \& Busby (2015) two more species belonging to Lathecla can be expected to 


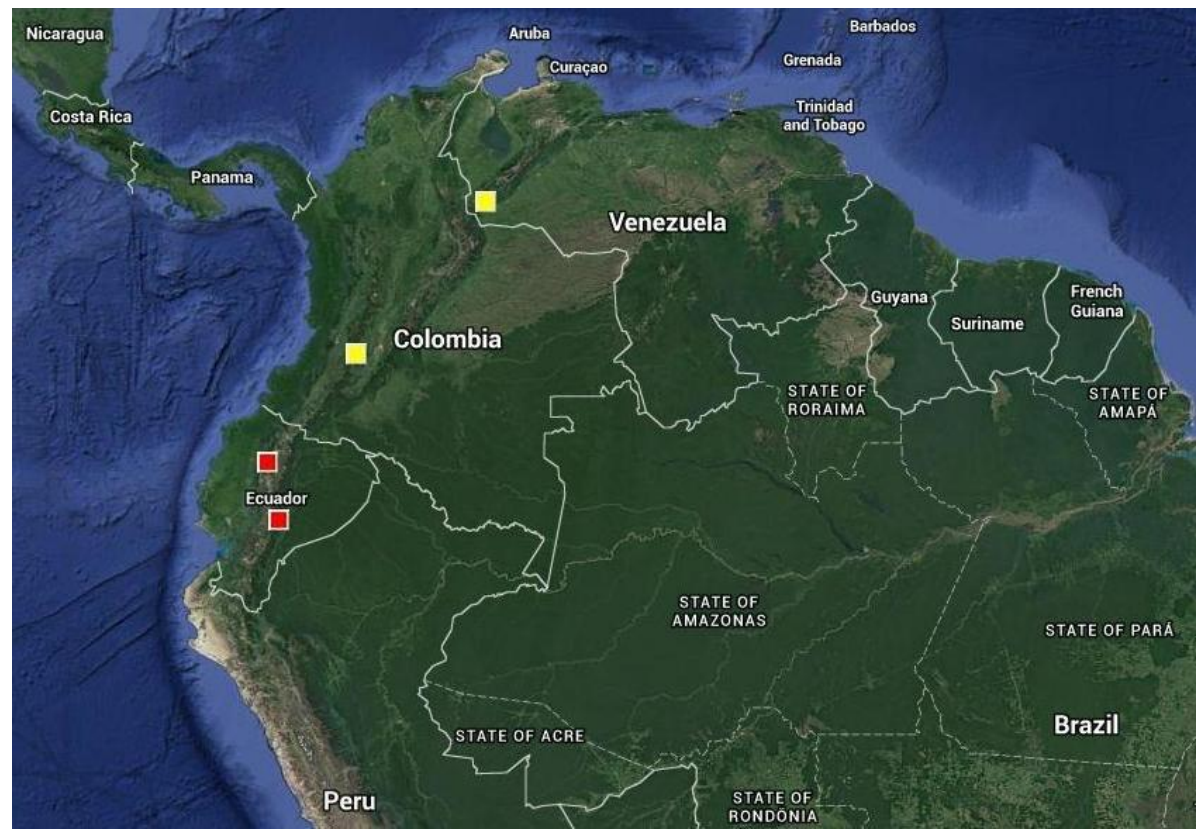

Figure 1. Distribution of Lathecla carolyna Busby, 2015; dark (red) squares: records of Robbins \& Busby (2015); light (yellow) squares: new records (copyright: GoogleMaps).

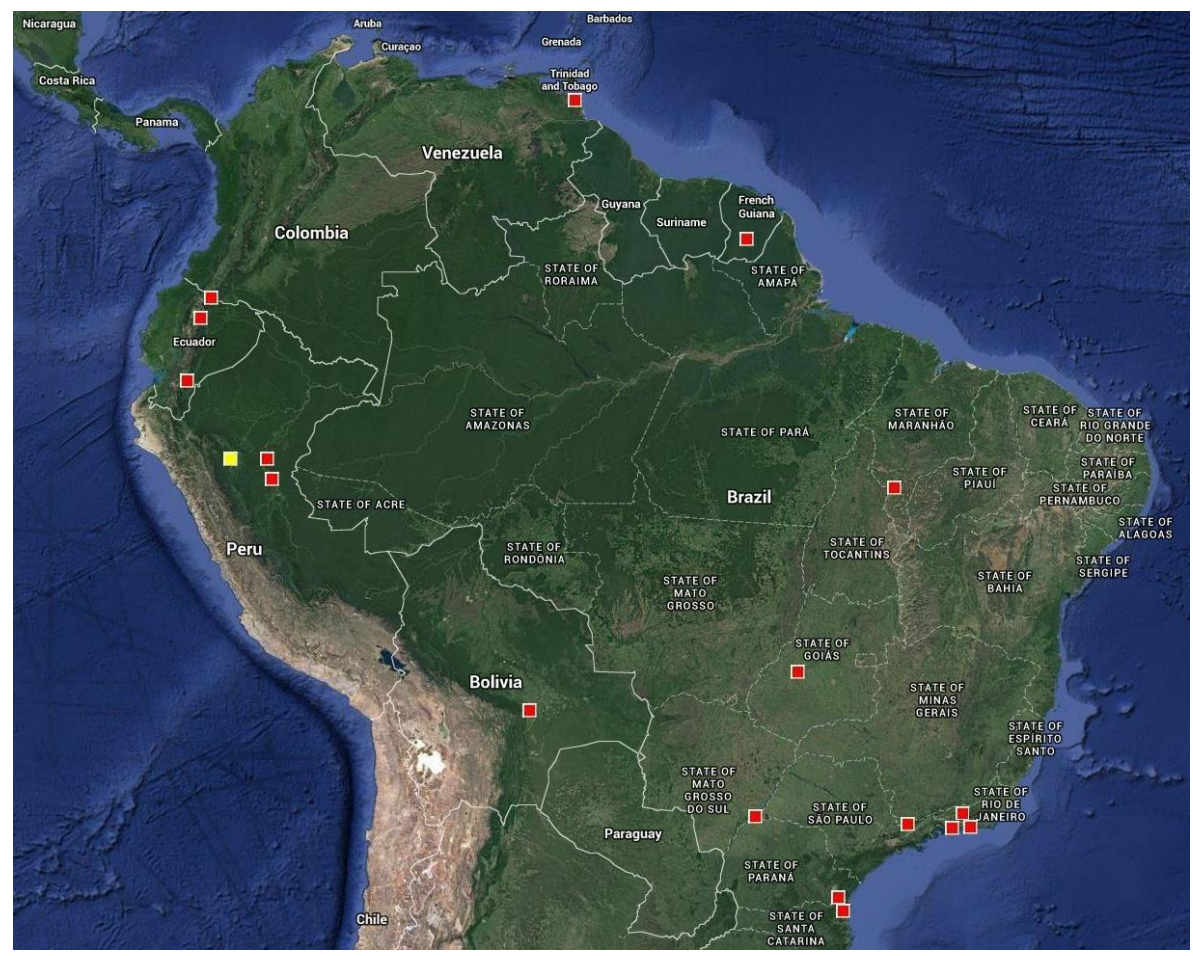

Figure 2. Distribution of Lathecla mimula (Draudt, 1920); dark (red) squares: records of Robbins \& Busby (2015); light (yellow) square: new record (copyright: GoogleMaps). 
occur in Venezuela, namely L. latagus (Godman \& Salvin, 1887) and L. mimula, both are lowland representatives of the genus considered to be primarily montane.

\section{Lathecla carolyna in Colombia.}

The collecting site of $L$. carolyna in Colombia is one of the best documented ones concerning the Lycaenidae fauna in the Neotropics (= GPS coordinates: N 3.496089; W 76.627479). It has been sampled over several years by several lepidopterists specializing in Lycaenidae (Prieto \& Dahners 2006, 2009). San Antonio is a hilltop in a montane wet forest, similar to the one where the type material of the species was collected in western Ecuador and in Venezuela.

Based on the known distribution patterns indicated by Robbins \& Busby (2015) two more species belonging to Lathecla can be expected to occur in Colombia, namely $L$. fernandezi and $L$. latagus; the former in montane, the latter in lowland wet forests.

\section{Lathecla mimula in Peru}

Robbins \& Busby (2015: 66) indicated that $L$. mimula is a lowland forest species representing the genus in the Amazonian biogeographic zone, and widely distributed in the South American continent from Trinidad via French Guyana to Brazil, and from Ecuador via Peru to Bolivia. However, it has been recorded only in two Peruvian sites, namely from Huánuco (Pachitea) and from Loreto (Contamana), rather close to each other geographically. The occurrence we recorded extends the known distribution in Peru somewhat $200 \mathrm{~km}$ northwest.

The site which claims the locality label, Juanjui (GPS coordinates: S 7.20785; W 76.739609), is a lowland town situated at the footsteps of the Peruvian Eastern Cordillera of the Andes in the far north of the country. The professional butterfly collector from whom the specimen originating operates in this area at lower elevation, so the specimen may well come from a premontane locality situated certainly far below the Abra Pardo Miguel pass $(2300 \mathrm{~m})$, in consistence with the data available.

Acknowledgements - Thanks are due to Mr. Pierre Boyer (France) and Mr. Gergely Katona (Hungary) for documenting museum specimens digitally, and helping in various technical aspects. An anonymous reviewer and Dr. R. K. Robbins (USA) made helpful suggestions improving the quality of the manuscript submitted.

\section{REFERENCES}

D'ABRERA, B. (1995): Butterflies of the Neotropical Region. Part VII. Lycaenidae. Hill House, Black Rock, Victoria, pp i-xi + 1098-1270.

DRAUDT, M. (1919-1920): I. Gruppe: Theclini. In. SEITZ, A. (Ed.) Die Gross-Scmetterlinge der Erde, Band 5. Die Amerikanische Tagfalter. Alfred Kernen Verlag, Stuttgart, p. 744-812.

PRIETO, C. \& DAHNERS, H. (2006): Eumaeini (Lepidoptera: Lycaenidae) del cerro San Antonio: Dinámica de la riqueza y comportamiento de "Hilltopping". Revista Colombiana de Entomología, 32(2): 179-190.

PRIETO, C. \& DAHNERS, H. (2009): Resource utilization and environmental and spatio-temporal overlap of a hilltopping Lycaenid butterfly community in the Colombian Andes. Journal of Insect Science 9(16): 1-12. doi: 10.1673/031.009.1601

RobBIns, R.K. (2004): Lycaenidae, Theclinae, Tribe Eumaeini. In. LAMAS G. (Ed.) Checklist: Part 4A. Hesperioidea - Papilionoidea. In. HEPPNER J B. (Ed.) Atlas of Neotropical Lepidoptera 5A. Association for Tropical Lepidoptera and Scientific Publishers, Gainesville, Florida, p. 118-137.

RobBins, R.K. \& DuARTE, M. (2004): Descriptions of new butterfly genera. Lycaenidae, Eumaeini. In. LAMAS G. (Ed.) Checklist: Part 4A. Hesperioidea Papilionoidea. In. HEPPNER J B. (Ed.) Atlas of Neotropical Lepidoptera 5A. Association for Tropical Lepidoptera and Scientific Publishers, Gainesville, Florida, p. 275-282.

RoBBINS, R.K. \& BUSBY, R.C. (2015): Evolutionary gain of male secondary sexual structures in the widespread Neotropical montane genus Lathecla (Lepidoptera, Lycaenidae, Eumaeini). Insect Systematics \& Evolution, 46: 47-78. doi: $\underline{10.1163 / 1876312 X-45032115}$ 